\title{
EFFECT OF FEEDING WITH THREE MULBERRY VARIETIES AND THEIR SEMI SYNTHETIC DIETS ON THE SILKWORM Bombyx mori L. \\ AL Rouz, $\mathrm{H}$. \\ Department of Plant Protection Fac. of Agric., Damascus Univ. Syria
}

\begin{abstract}
The study was carried out during Spring 2009 in the Cairo University Department of the Economic Entomology and Pesticides. The effect of the leaves of three mulberry varieties (1- Morus rubra 1 L. 2 - Morus rubra 2 L. 3-Morus nigra L. ) and the mixed of the three varieties without propolis and with Propolis and their three different semi artificial diets of food on the grown fourth and fifth instars larvae of Bombyx mori L . Larvae on their rate of growth, duration, pupal weight, silk cocoon, sex ratio, number of egg laying and the coefficient of digestibility was all determined.

Larval fed on leaves of Morus rubra $1 \mathrm{~L}$. and the mixed of the three varieties with proplis were showed a significant different characters .
\end{abstract}

\section{INTRODUCTION}

The silkworm Bombyx mori L. has been considered as a monophagous insect and only the mulberry leaves were known as the silkworm natural food for a long time. It is quite versatile unique species due to its domestication for a centuries, its adaptability to artificial diet is not difficult (Chowdhary , 1996).

Feeding of late instars ( $4^{\text {th }}$ and $5^{\text {th }}$ larval instars) by natural mulberry leaves, cost lot of money and labor workers. So, instead of using the natural leaves the semisynthetic diets may be more promising to save money ,time and labor . As detected by Eid et al. , 2007, Hiro et al. 1997 and Jian -Hu et al. 1998 .

In the sericulture industry, the improvement of the cocoon quality as well as quantity, which is affected by silkworm food, is very important (Matsura,1994) and the development of natural silk industry largely depends upon the use of improved of silkworm production of high quality leaves through better mulberry varieties and method of rearing (Tayade and Jawal, 1984). According to Choudhary et al. (1991) the quality of mulberry leaves play an important role on success of sericulture and directs its economics.

The principal components of mulberry leaves are water and dry matter which is consisted of protein, carbohydrates, fats, inorganic salts and vitamins. All of these elements are essential nutrients for the physiological function of the silkworm .The nutritional value of the leaves varies greatly according to different factors such as variety of mulberry leaves, position and maturity of leaves, soil texture, fertilization, photoperiod and season ( WuPang Chuan and Chen Da-Chuang , 1987 , Horie et al., 1978, Mahmoud, 2000). And there for the present investigation deal with three kinds of mulberry Morus rubra $1 \mathrm{~L}$. ,Morus rubra $2 \mathrm{~L}$., and Morus nigra L. and their effects on some biological aspects on Bombyx mori L.

Propolis is one of the valuable apicultural products. Propolis has an activity against many pathogens ( Hegazi et al., 2000 , Ftayeh et al.,2003) the antibacterial, antifungal and antiviral effects of Propolis were observed by 


\section{Al Rouz, $H$.}

(Cheng and Wong, 1996, El-Maasarawy, 1995, Shub et al., 1981 and Giurgea et al., 1983 ). Propolis can be used in scientific medicine. Also, microscopic examination appeared that no flacherie disease was observed among treated larvae of Bombyx mori L. with Propolis (Nour et al., 1996) . Studies on rate of growth, duration ,pupal weight, silk cocoon, sex ratio, number of egg laying and the coefficient of digestibility were carried out by Blattacharyia and Waldbawer, 1969 .

The aim of the present work is to evaluate the leaves of the three mulberry varieties, the mixed of the three varieties without propolis and with propolis and their semi-artificial diets on the grown fourth and fifth instars larvae .

\section{MATERIALS AND METHODS}

\section{1-Silkworm Resource :}

The silkworm race used was S A 105 ; eggs of silkworm race were obtained from the Sericulture Research Department of Plant Protection Research Institute, Ministry of Agriculture ,Giza -Egypt . The study was carried out during Spring 2009 in the Cairo University Department of the Economic Entomology and Pesticides .

\section{2 - Rearing Technique :}

Rearing silkworm and experimental technique were carried out under laboratory condition ( $26^{\circ} \mathrm{C} \pm 20^{\circ} \mathrm{C}$ and $65 \pm 5 \mathrm{R}$. H .) .

\section{The First Experiment :}

Young larvae (first, second and third instars )were reared on fresh mulberry leaves of Morus alba Var Kukoso, 27. Experimental treatments were carried out on the grown fourth and fifth instars larvae. Five treatments each contained 30 larvae of $\left(4^{\text {th }}\right.$ and $5^{\text {th }}$ instars). Leaves of the three mulberry were harvested and separately fed to the larvae during the grown larval stage. (1- Morus rubra 1 L., 2-Mourus rubra 2 L., 3-Morus nigra L . (Fig.1), 4-mixed of 1, 2, 3, and 5-mixed of 1,2, 3 ,with solution of 0,02 propolis). An equal amount of leaves was given to each batch four times a day .

\section{The Second Experiment :}

The same mulberry varieties leaves used in the previous experiment were used in three treatments of semi-artificial diets as the following ingredients:

- Powder of dried leaves $55 \%$ ( 1 - Morus rubra 1 L. 2 - Morus rubra 2 L. 3 Morus nigra L.), Casein $10 \%$, Agar - Agar ( powder ) $15 \%$, Sucrose 10 $\%$ Ascorbic Acid $3 \%$, Propolis $2 \%$, Sodium benzoate $0.2 \%$ and water to terminate the soft quality diet which represent the best tasty food for larvae. .

Larvae were fed during the fourth instar only on artificial diet then followed during the fifth instar by natural leaves from the same kind in the diet .

Diet 1 - Powder of dried leaves Morus rubra $1 \mathrm{~L}$.

Diet 2 - Powder of dried leaves Morus rubra 2L.

Diet 3 - Powder of dried leaves Morus nigra L . 


\section{The Thhrd Experiment :}

The same previous technique used were followed only for 5 days feeding in the grown $5^{\text {th }}$ larval instar semi artificial diet then the rest of days were fed naturally on theire fresh leaves .

Three replicates of each treatment were used, each replicate containing 30 larvae .The diet was introduced to larvae as one meal per day and then the reminder kept in the refrigerator. the coefficient of digestibility were calculated according to the equation of Blattacharyia and Waldbawer, 1969 .

$$
\text { Weight of food ingested - weight of faece voided . } 100
$$

weight of food ingested

Data were recorded for different parameters as fifth instars duration in days, total larval duration in days, larval body weight in $\mathrm{mg}$., larval mortality percentage , weight of silk gland in mg. , pupal weight and silk cocoon weight in $\mathrm{mg}$. sex ratio and number of egg laying were also detected.

The data obtained were analysed following t- test and Fisher test according to Snedecor and Cochrian., 1967 .

\section{RESULTS AND DISCUSSION}

The larval duration $4^{\text {th }}$ and $5^{\text {th }}$ instars which represent the long feeding period for this insect seemed to be shortened after the feeding by $M$ rubra 1 $\mathrm{L}$. leaves and their artificial diet contained mixed leaves with Propolis ( 34.3 and 35.6 days) in comparison with the other treatments (Table 1, 2 and 3 ). these results confirmed these found by Eid et al., 2007 , El-Maasarawy , 1995 and Mahmoud, 2000.

Larvae fed on diet 1 (Morus rubra $1 \mathrm{~L}$.) and leaves of Morus rubra 1 L. reveal best results compared with other varieties (Table1, 2, 3) in weight of silk gland and silk cocoon weight with significant difference. These results emphasize the finding of Horie et al.(1978), who noticed that elevation of dietary protein results in acceleration of growth and silk yield. Also, nearly 70 percent of silk protein produced by silkworm are directly derived from the proteins of the mulberry leaves Bariet et al. (1985), that mean, the protein content of M. rubra may be the best .

Accumulation of protein in larvae depends largely upon the concentration of carbohydrate (soluble sugar and starch) in the leaves (Sastri, 1962). Hence a comparatively higher carbohydrate content of leaves may prove a beneficial in growth of the silkworm. Moreover, the average digestibility or soluble carbohydrate content of mulberry leaf may have beneficial effect on the growth of silkworm . Larvae fed on mixed leaves 1,2,3 with propolis $2 \%$ reveal the best result compared with other variety (Table 1 ) for the minimum duration days of larvae . 
Al Rouz, $H$.

T1-2-3

8196 
Larval body weight, weight of silk gland, pupal weight, silk cocoon weight and number of egg laying. These results emphasize the finding of ElMaasrawy,(1995) when Propolis extract was used, He found a high increase in the weight of pupa and effect on productivity of silk, and anabolic effect on silkworm larvae and such results have a lot of benefits for the production of eggs as an economic phase of silkworm rearing .

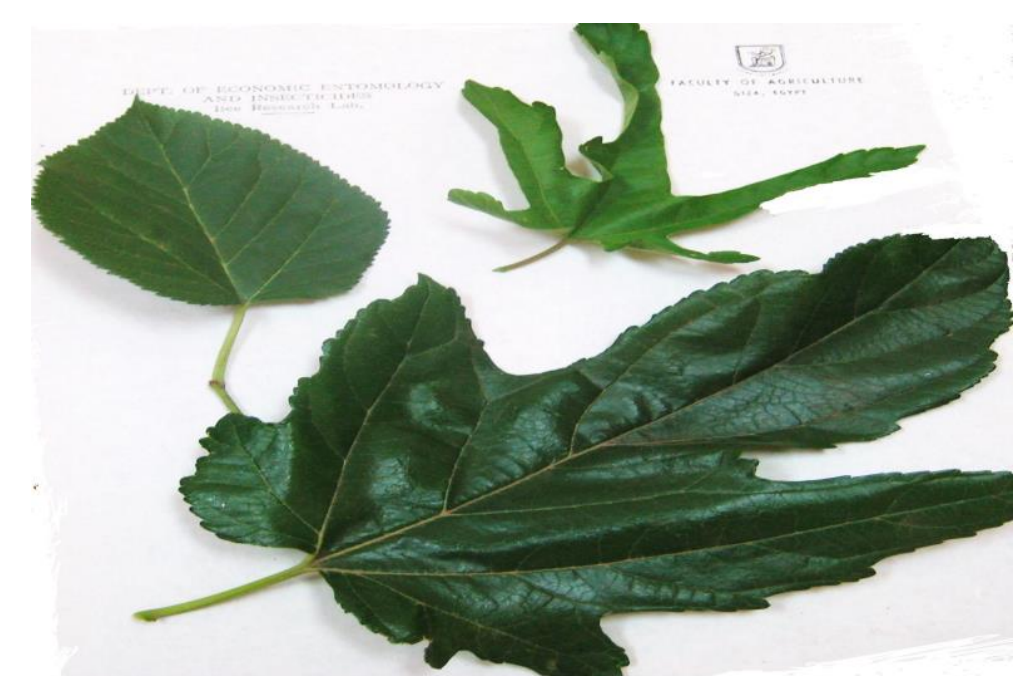

Fig. 1 - The three shapes of the types of mulberry leaves.

a-Morus rubra 1 b-Morus rubra 2 c-Morus nigra.

From Table 1, the treatment of mixed leaves from the three varieties with propolis range in the first, resulted the heavier fed larvae (390.0mg.) followed by larvae fed on the variety of $\mathrm{M}$. rubra $1 \mathrm{~L}$. (368.6 mg.) but larvae fed on M. rubra $2 \mathrm{~L}$. leaves showed the lowest larval body weight $(221.0 \mathrm{mg}$.) compared with the rest of treatments. These results emphasize the finding of Mahmoud, (2000) These variation in larval growth and silk yield are due to the difference nutrient composition of the different mulberry varieties. This agrees with Bhaskar et al. (1999). Who concluded that the nutritional status of mulberry leaf offered to silkworm largely influenced the growth and development .

Generally natural feeding results the best economic characters produced. Otherwise artificial feeding for necessity and shortage of labor and leaves may be a nice option to save economic breading continuity .

The results of weight of silk gland, pupal weight, silk cocoon weight number of egg laying and coefficient of digestibility percentage they all go in line with the same trend obtained previously (El-Maasarawy,1995, Mahmoud, 2000, Hosny et al., 2002, Rahatulla et al., 2005, Eid et al., 2007)

As a general conclusion from the obtained results, the treatment of feeding larvae on the Morus rubra $1 \mathrm{~L}$. variety showed excellent results in all parameters estimated. And deposited eggs produced from this treatment 


\section{Al Rouz, $H$.}

were kept under the laboratory, condition ( $28 \mathrm{C}, 50 \%$ R.H) during the spring season (2009) for 15 days and suddenly they hatched successfully for about $95 \%$. Therefore, this case may explain the importance of this variety of leaves for the silk production as a second silk yield in the same spring season because these larvae were followed by feeding on the artificial diet which contained about $55 \%$ from their constituents of dried leaves of the variety $\mathrm{M}$. rubra $1 \mathrm{~L}$. and continued till the end of the larval stage. This result may lead to continue the breeding of these larvae on fresh leaves found and still fresh and useful for feeding such larvae.

\section{Acknowledgement:}

The author is very indebted to Professor. Dr.M.S. Salem and Professor. Dr.S. El-Maasarawy form Cairo university Department of the Economic Entomology and Pesticides for their considerable help, and making helpful suggestions and criticism in this manuscript

\section{REFERENCES}

Bari, M.A.;R. Islam and M. A. Salam (1985). Feeding effects of three mulberry varieties on Nistari Race of silkworm Bombyx mori L.Bangladesh J. Zool. 13(1): :13-17.

Bhaskar,R. N.; K. Govindan; M . C. Devaiah; and D. Radhakrishna (1999). Influence of mulberry leaf nutrition and Bm CPV infection on disease development and some cocoon traits in Bombyx mori L. Sericologia, 39 (1): 55-61.

Blattacharya,A .K. and G. PWaldbawer (1969). Faecal uric acid as an indicator in the determination of food utilization .J . Insect Physiol . Vol. $15,: 1129-1123$

Cheng, P . C. and G. Wong (1996) . Honey bee prppolis : prospects in medicine . Bee-World ;77 ( 1$): 8-15$.

Choudhury, P . C.; P. Shukla; A. Chosh ; B. Mallikarjour and K. Sengupta (1991). Effect of spacing crown height and method of pruning on mulberry leaf yield, quality of cocoon yield. Indian J. Seric. 30 (1): 4653 .

Chowdhary, S.K. (1996). Rearing of the silkworm, Bombyx mori L . on artificial diets. Retrospect and prospects .Sericologia, 36 (3),407-418.

Ftayeh , M. A. ; H. Al Rouz and A. Al Buraky. (2003).Apiculture and Sericulture . Fac. Agric . Univ .Damascus, 558.

Eid, M. A. A.; S. A. S El-Maasarawy; M. A. N. Soud and R .A Zinhoum. (2007). Effect of artificial diets on the silkworm, Bombyx mori L. of the production . J. Agric. Sci. Mansoura Univ., 32 (9): 7757-7764

El-Masssarawy, S. A .S.(1995). Anabolic effect of Propolis extract on the silkworm Bombyx mori L. Bull .Ent.Egypt.73,41-50 .

Giurgia, R .;H .Popescu.; C. POlinicenco. (1983). Effect of standardized pprpolis extrat ( SPE ) on immune reaction. Clujul Medical.,56 (1) :7376 .

Hegazi, A .G,; F. K . A El-Hady and F .A .M .Abd-Allah.(2000). Chemical composition and antimicrobial activity of European Propolis . Zeitschrift fur Naturforschung Section C, Biosciences . 55 (12): 70-75 .

Hiro, A. Y.; S. Hiroshi and Y. Toshio .(1997).Recent studies on low- cost artificial diet and polyphagous silkworm in Japan. Xv11th Inter. Seric.Comm. Congr. 
Horie, Y,; T.Inokuch and K.Watanabe . (1978).Quantitative study of food by the silkworm, Bombyx mori L. through its life cycle. Bull. Seri. Expt. Stn.27: $571-578$.

Hosny, A. and M. S . Mahmoud. (2002). Cocoon production of Bombyx mori $\mathrm{L}$. raised on leaf crop of two types of mulberry fields around the year. $2^{\text {nd }}$ Inter. conf .Plant Protection Research Institute, Cairo, Egypt.,(1):233-236.

Jian-Hui, H.; Z. Zhong-Shui and X . Jun-Liang . (1998). Feeding silkworm once with artificial diet through the first two instars and then with mulberry foliage during remaining instars and its cost analysis. Acta Agriculture zhejianggensis ,10 (5) : 245-249.

Mahmoud, S. M. (2000). Feeding effects of five mulberry varieties on the silkworm , Bombyx mori L. Egypt. J . Appl.Sci; 15 (6) 253-261 .

Matsura, Y. (1994). Utilization of blood meal as source of dietary protein : 1Blood meal used as dietary protein for silkworm, Bombyx mori L. Jarq, $28(2): 133-137$.

Rahmatulla,V. K .; S. Z.Haque; G .S .Himantharaj.; G .S .Vindya and R .K. Rajan. (2005). Food ingestion, Assimilation and conversion efficiency of mulberry silkworm Bombyx mori L .Int. J. Indust.Entomol.11 (1):1-12.

Sastri , B. N. (1962). Wealth of India, CSIR, New Delhi , 6:429-439.

Shub, T .A .; K . A . Kagramonova ; S .D .Voropaeva and G .Kivman.( 1981) . Effect of prpolis on strains of staphylococcus aureus resistant to antibiotics . Aantibiotiki, 26 (4) :268-271.

Senedecor, G.W .and W. G Cochian. (1967). Statistical Methods. Iowa, USA. The lowa state university press.

Tayade, D .S . and M. D .Jawwale. (1984). Studies on the comparative performance of silkworm races against different varieties of mulberry under Marathwada condition. Sericologia 23 (3):361-364.

Wu pang- Shuan and Chen Da- Chuang . ( 1988 ). Silkworm rearing.FAO Agricultural Services Bulletin . 73(2):12-13 .

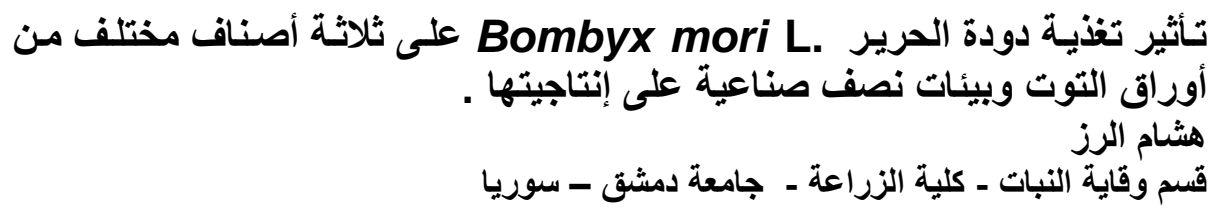

تمت در اسة تأثير تغذية دودة الحرير . Bombyx mori L على ثلاثة أصناف مختلفة من التوت

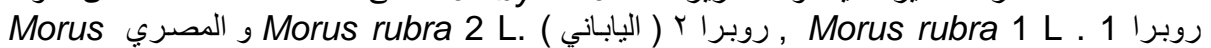
عigra L.

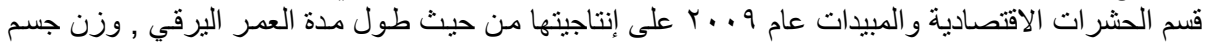

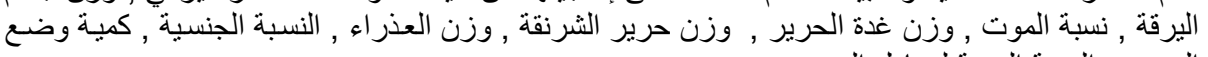

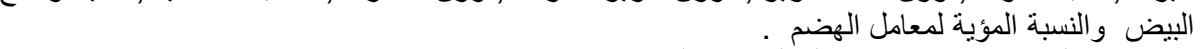

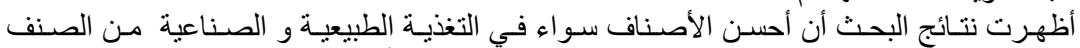

Morus rubra 1 L .

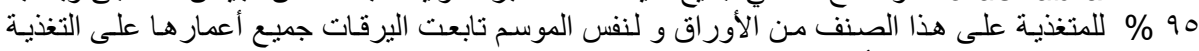

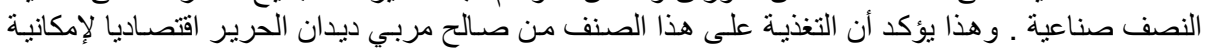

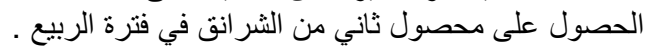

a 
Al Rouz, $H$. 
Table 1- Effect of feeding larvae of silkworm bombyx mori L. on different mulberry varieties

\begin{tabular}{|c|c|c|c|c|c|c|c|c|c|c|}
\hline \multicolumn{2}{|r|}{ Treatments } & $\begin{array}{c}\text { Larval } \\
\text { duration in } \\
\text { (days) }\end{array}$ & $\begin{array}{l}\text { Larval body } \\
\text { weight (mg.) }\end{array}$ & Mortality \% & $\begin{array}{c}\text { Weight of silk } \\
\text { gland (mg.) }\end{array}$ & $\underset{\text { (mg.) }}{\text { Pupla weight }}$ & $\begin{array}{l}\text { Silk cocoon } \\
\text { weight (mg.) }\end{array}$ & \multicolumn{2}{|c|}{$\begin{array}{c}\text { Sex } \\
\text { Ratio \% }\end{array}$} & $\begin{array}{c}\text { Number of egs } \\
\text { laying }\end{array}$ \\
\hline 1 & Morus rubra $1 \mathrm{~L}$. & $\begin{array}{r}a \\
34.3 \pm 0.14\end{array}$ & $\begin{array}{r}\text { a } \\
368.6 \pm 30.57\end{array}$ & 0 & $\begin{array}{r}a \\
658.3 \pm 35.11\end{array}$ & $\begin{array}{r}\mathrm{ca} \\
1206.7 \pm 211.6\end{array}$ & $\begin{array}{c}\mathrm{a} \\
393.3 \pm 11.88\end{array}$ & 37 & 63 & $\begin{array}{r}a \\
535.9 \pm 22.67\end{array}$ \\
\hline 2 & Morus rubra $2 \mathrm{~L}$. & $\begin{array}{c}\mathrm{b} \\
37.5 \pm 0.42 \\
\end{array}$ & $\begin{array}{r}c b \\
221.0 \pm 42.45\end{array}$ & 0 & $\begin{array}{r}\mathrm{b} \\
466.7 \pm 39.28 \\
\end{array}$ & $\begin{array}{r}\mathrm{a} \\
1170.0 \pm 207.0 \\
\end{array}$ & $\begin{array}{c}\mathrm{b} \\
353.3 \pm 10.64 \\
\end{array}$ & 43 & 57 & $577 \pm 14.96^{\mathrm{a}}$ \\
\hline 3 & Morus nigra L. & $36.9 \pm 0.30$ & $\begin{array}{r}c b \\
263.8 \pm 40.86 \\
\end{array}$ & 0.03 & $\begin{array}{r}a b \\
558.3 \pm 35.11 \\
\end{array}$ & $\begin{array}{c}b \\
1043.3 \pm 237.3\end{array}$ & $\begin{array}{c}\text { C } \\
293.1 \pm 15.92 \\
\end{array}$ & 46 & 54 & $\begin{array}{r}a \\
494.3 \pm 12.46\end{array}$ \\
\hline 4 & Mixed of $(1,2,3)$ & $\begin{array}{c}b \\
36.9 \pm 0.28\end{array}$ & $\begin{array}{r}\mathrm{ac} \\
294.8 \pm 39.02 \\
\end{array}$ & 0 & $525.0 \pm 22.73$ & $\begin{array}{c}\mathrm{ab} \\
1070.4 \pm 315.8\end{array}$ & $323.3 \pm 12.61$ & 60 & 40 & $\begin{array}{r}\mathrm{a} \\
526.1 \pm 3232\end{array}$ \\
\hline & $\begin{array}{l}\text { Mixed of } \\
\text { propolis } 0.02\end{array}(1,2,3)+$ & $35.6 \pm 0.27$ & $\begin{array}{r}\mathrm{ac} \\
390.0 \pm 34.56\end{array}$ & 0 & $\begin{array}{c}\mathrm{b} \\
650.0 \pm 45.45\end{array}$ & $\begin{array}{c}\mathrm{C} \\
1313.3 \pm 222.4\end{array}$ & $\begin{array}{r}b \\
413.3 \pm 9.42\end{array}$ & 50 & 50 & $\begin{array}{r}b \\
654.8 \pm 30.12\end{array}$ \\
\hline
\end{tabular}

Values in a column followed by the same small letter are not significantly different $(P<0.05)$

Table 2- Effect of feeding the grown $4^{\text {th }}$ instars larvae on semi-artificial diets, then continued the $5^{\text {th }}$ instant on their fresh leaves:

\begin{tabular}{|c|c|c|c|c|c|c|c|c|c|c|}
\hline \multirow{2}{*}{ Treatments } & \multirow{2}{*}{$\begin{array}{c}\text { Larval } \\
\text { duration in } \\
\text { (days) }\end{array}$} & \multirow{2}{*}{$\begin{array}{l}\text { Larval } \\
\text { body } \\
\text { weight } \\
(\mathrm{mg} .)\end{array}$} & \multirow{2}{*}{$\underset{\%}{\operatorname{Mortality}}$} & \multirow{2}{*}{$\begin{array}{l}\text { Weight of silk } \\
\text { gland (mg.) }\end{array}$} & \multirow{2}{*}{$\begin{array}{c}\text { Pupla weight } \\
\text { (mg.) }\end{array}$} & \multirow{2}{*}{$\begin{array}{l}\text { Silk cocoon } \\
\text { weight (mg.) }\end{array}$} & \multicolumn{2}{|c|}{$\begin{array}{c}\text { Sex } \\
\text { Ratio \% }\end{array}$} & \multirow{2}{*}{$\begin{array}{l}\text { Number of } \\
\text { egg laying } \\
\text { Female }\end{array}$} & \multirow{2}{*}{$\begin{array}{l}\text { Coefficient } \\
\text { of } \\
\text { digestibility } \\
\text { percentage }\end{array}$} \\
\hline & & & & & & & Male & Female & & \\
\hline Diet1 Morus rubra 1 & $\begin{array}{r}b \\
37.1 \pm 0.18\end{array}$ & $\begin{array}{r}a \\
70.6 \pm 15.7\end{array}$ & $\begin{array}{r}\mathrm{a} \\
10.0^{2}\end{array}$ & $583.3 \pm 19.91$ & $\begin{array}{r}a \\
1004.3 \pm 69.38\end{array}$ & $\begin{array}{r}\mathrm{a} \\
271.4 \pm 20.14\end{array}$ & 54.55 & 45.45 & $500.7 \pm 22.02$ & $\begin{array}{c}a \\
84.6 \pm 0.57\end{array}$ \\
\hline Diet2 Morus rubra 2 & $\begin{array}{r}a \\
40.8 \pm 0.46\end{array}$ & $63.0 \pm 22.0$ & $\begin{array}{r}\mathrm{a} \\
16.5\end{array}$ & $\begin{array}{r}a \\
391.3 \pm 24.01\end{array}$ & $\begin{array}{c}\mathrm{a} \\
957.1 \pm 69.95\end{array}$ & $\begin{array}{r}b \\
207.1 \pm 22.99\end{array}$ & 45.55 & 54.55 & $\begin{array}{r}\mathrm{a} \\
426.8 \pm 40.82\end{array}$ & $\begin{array}{r}b \\
77.2 \pm 0.82\end{array}$ \\
\hline Diet 3 (Morus nigra L) & $\begin{array}{c}a \\
39.8 \pm 0.39\end{array}$ & $\begin{array}{r}a \\
83.4 \pm 23.7\end{array}$ & $\begin{array}{r}a \\
13.3\end{array}$ & $\begin{array}{r}a b \\
483.3 \pm 19.90\end{array}$ & $\begin{array}{r}a \\
914.3 \pm 84.81\end{array}$ & $\begin{array}{r}a \\
a \\
270.2 \pm 13.00\end{array}$ & 60 & 40 & $502.3 \pm 24.43$ & $\begin{array}{r}a \\
75.4 \pm 0.56\end{array}$ \\
\hline
\end{tabular}

Values in a column followed by the same small letter are not significantly different $(\mathbf{P}<0.05)$

Table 3- Effect of feeding the grown $5^{\text {th }}$ instars larvae on semi-artificial diets, then continued on their fresh leaves:

\begin{tabular}{|c|c|c|c|c|c|c|c|c|c|c|}
\hline \multirow[b]{2}{*}{ 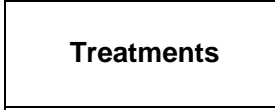 } & \multirow{2}{*}{$\begin{array}{c}\text { Larval } \\
\text { duration in } \\
\text { (days) }\end{array}$} & \multirow{2}{*}{$\begin{array}{l}\text { Larval body } \\
\text { weight(mg.) }\end{array}$} & \multirow{2}{*}{$\underset{\%}{\text { Mortality }}$} & \multirow{2}{*}{$\begin{array}{l}\text { Weight of } \\
\text { silk gland } \\
\text { (mg.) }\end{array}$} & \multirow{2}{*}{$\begin{array}{c}\text { Pupla weight } \\
\text { (mg.) }\end{array}$} & \multirow{2}{*}{$\begin{array}{l}\text { Silk cocoon } \\
\text { weight (mg.) }\end{array}$} & \multicolumn{2}{|c|}{$\begin{array}{c}\text { Sex } \\
\text { Ratio \% }\end{array}$} & \multirow{2}{*}{$\begin{array}{l}\text { Number of } \\
\text { egg laying } \\
\text { Female }\end{array}$} & \multirow{2}{*}{$\begin{array}{l}\text { Coefficient } \\
\text { of } \\
\text { digestibility } \\
\text { percentage }\end{array}$} \\
\hline & & & & & & & Male & Female & & \\
\hline th & & & & $\begin{array}{c}\mathrm{a} \\
570.8 \pm 27.53\end{array}$ & & $344.5 \pm 15.11$ & & 53 & & \\
\hline et 2 Morus rubra 2 & & $\begin{array}{c}\mathrm{a} \\
53.84\end{array}$ & & $431.0 \pm 32.41$ & $1060.5 \pm 149.65$ & & & & $\begin{array}{c}a \\
509.3 \pm 24.89 \\
\end{array}$ & \\
\hline & $7.7 \pm 0.32^{a}$ & $\begin{array}{c}\mathrm{a} \\
994.0 \pm 49.70\end{array}$ & 10 & $\begin{array}{c}a \\
523.4 \pm 23.51\end{array}$ & $\begin{array}{r}\mathrm{b} \\
986.3 \pm 151.73 \\
\end{array}$ & $285.4 \pm 14.32$ & 51 & 49 & $\begin{array}{r}\mathrm{a} \\
498.2 \pm 16.54\end{array}$ & $94.9 \pm 0.41$ \\
\hline
\end{tabular}

Values in a column followed by the same small letter are not significantly different $(P<0.05)$ 
